\title{
Water harvesting pond and recycling for sustainable crop production in doubling income in Kandhamal district of Odisha, India
}

\author{
Ch. Rajendra Subudhi* , Sagara Chandra Senapati and Rageswari Subudhi \\ Department of Soil and Water Cons. and Eng, CAET, OUAT \\ *Email: rsubudhi5906@gmail.com, +919437645234
}

\begin{abstract}
A trial was conducted during 2007 to 2009 at All India Coordinated Research Project for Dry land Agriculture Phulbani, Odisha, India., with an objective to obtain the water loss and economics of the lined ponds. There were three treatments T1-Lined pond with soil cement plaster $(6: 1) 8 \mathrm{~cm}$ thickness, T2-Unlined pond, T3-No pond.10\% of the cropped area was dug for construction of the pond in Lined and Unlined pond treatments. The size of the pond is $7 \mathrm{~m}$ top widths, $1 \mathrm{~m}$-bottom width, $3 \mathrm{~m}$ heights, and 1:1side slope. The water loss was $17 \mathrm{lit} / \mathrm{day} / \mathrm{m}^{2}$ in lined pond and $831 \mathrm{lit} /$ day $\mathrm{m}^{2}$ in unlined pond. Provision of dugout pond in $10 \%$ area of the plot at the downstream side with $8 \mathrm{~cm}$ thickness soil cement plaster (6:1) gave $41 \%$ higher cauliflower equivalent yield compared to no pond. The B:C ratio was found to be 2.25 in lined pond. The light textured well-drained upland soils in North Eastern Ghat Zone provide scope for cultivation of vegetables during rainy season. Harvesting of this run-off water in farm pond with proper lining will conserve the run-off water and recycling of this water for lifesaving irrigation will protect the crop from drought/dry spell grown in $90 \%$ of land area. The ponds will be helpful for sustainability in productivity of dry land crops. Soil structure and organic matter status decide the water holding capacity of the soil. Keeping those points in view, the present experiment involving two water management systems (no pond and pond) has been designed.
\end{abstract}

Key words: Materials, rainwater, harvesting, sustainable, crop, production

Paper cited: Subudhi, C.R.; Senapati, S.C. and Subudhi, R. (2019). Water harvesting pond and recycling for sustainable crop production in doubling income in Kandhamal district of Odisha, India. South Asian Journal of Food Technology and Environment, 5(2): 836-839.

\section{Introduction}

The light textured well-drained upland soils in North Eastern Ghat Zone provide scope for cultivation of vegetables during rainy season. The intermittent dryspells and terminal drought affect the performance of those high value crops in most of the years. About $25 \%$ of the rainfall is lost as run-off. Harvesting of this run-off water in farm pond with proper lining will conserve the run-off water and recycling of this water for lifesaving irrigation will protect the crop from drought/dryspell grown in $90 \%$ of land area. The ponds will be helpful for sustainability in productivity of dryland crops. Soil structure and organic matter status decide the water holding capacity of the soil. Keeping those points in view, the present experiment involving two water management systems (no pond and pond) has been designed. Ex situ water management is one type of management of land and conservation of rainfall excess which not only helped the havoc at the lower side but also provides life saving irrigation for a second crop. Many authors have focused on On Farm Reservoir (OFR) with lined and unlined system for increasing the yield and economic condition of the farmers. Different authors recently studied the effect of lined and unlined pond in India. Some them are discussed below. Panigrahi and Panda (2003) found the average increase in yield of rice and mustard yield due to supplemental irrigation from the OFR is found to be $29.2 \%$ and $22.3 \%$ more over the average yield of corresponding crops under rainfed condition The side slope of the harvesting pond was maintained as 1:1 
(Panigrahi and Panda, 2003). The optimum size of OFR was found to be $12 \%$ of the land area gave benefit cost ratio internal rate of return and payback period of $1.22,16.1 \%$ and 13 years respectively with the cropping system of rice mustard (Panigrahi et al., 2005). The benefit-cost value of lined and unlined OFRs occupying $10 \%$ of the farm area becomes 1.65 and 2.70, respectively. Surajbhan (2009) found that the effect of rain water harvesting and ponds in different parts of the countries were suitable for soil and water conservation and increasing crop yield and economics of the farming communities. The objectives of the present study are as follows

1. To quantify the increase in land productivity and land use efficiency through on-farm water harvesting

2. To quantify the water/seepage loss in different ponds

\section{Materials and Methods}

$10 \%$ of the cropped area was dug for construction of the pond in Lined (Fig.1) and unlined pond treatments. Size of the pond is $7 \mathrm{~m}$ top width, $1 \mathrm{~m}$ bottom width, $3 \mathrm{~m}$ heights, and 1:1 side slope. The water harvested in pond was reutilized for the pumpkin crop, which was sown only in Lined pond treatment, as there was no water available in unlined pond so the crop was not sown there.

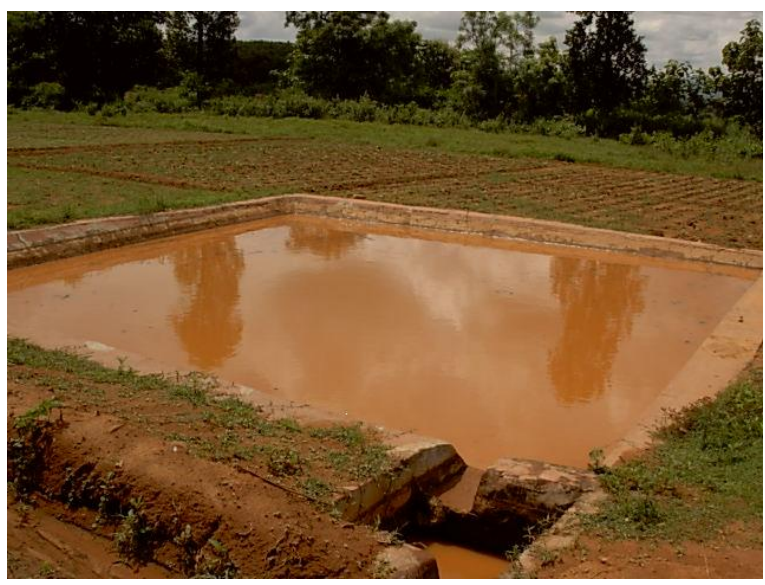

Fig.1: Lined pond

$\begin{array}{ll}\begin{array}{l}\text { Treatment } \\ \text { details }\end{array} & \begin{array}{l}\mathrm{T}_{1} \text {-Lined pond with soil } \\ \text { cement plaster in } 6: 1 \text { ratio } \\ (8 \mathrm{~cm} \text { thickness })\end{array} \\ & \begin{array}{l}\mathrm{T}_{2} \text { - Unlined pond } \\ \\ \mathrm{T}_{3} \text { - No pond (control) }\end{array} \\ \begin{array}{l}\text { Experimental } \\ \text { design }\end{array} & : \text { No design }\end{array}$

Plot size (sq.m)

a) Gross plot : $30 \mathrm{~m} \times 15 \mathrm{~m}$

b) Net plot : $28.2 \mathrm{~m} \times 12.3 \mathrm{~m}$

Spacing $(\mathrm{cm})$ : Cauliflower- $45 \mathrm{~cm} \times 45$

$\mathrm{cm}$

Radish- $45 \mathrm{~cm} \times 5 \mathrm{~cm}$

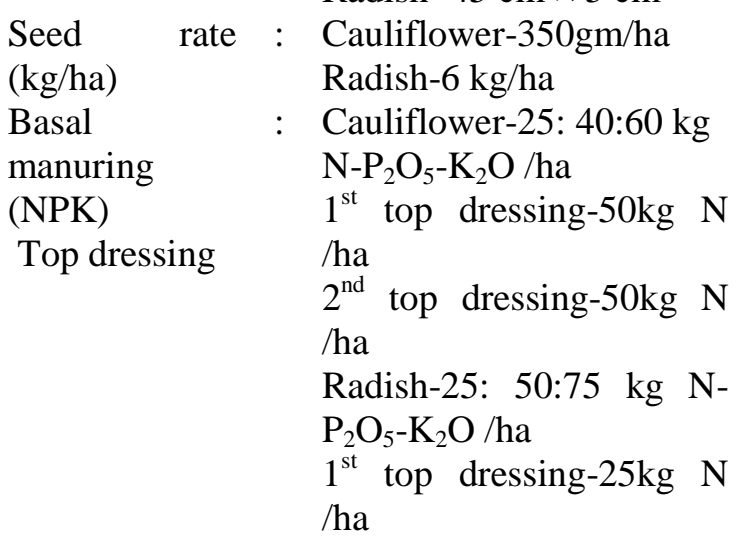

Previous crop : As trial was conducted at and fertilizer same place so same applied fertilizer as mentioned above.

\section{Results and Discussion}

The mean yield was highest $(7.51 \mathrm{t} / \mathrm{ha})$ (Table 1) in lined pond and water loss was lowest (235.8 lit/day) (17.06 lit/day $\left./ \mathrm{m}^{2}\right)$ in lined pond. The mean rabi radish yield in lined pond was $23.775 \mathrm{t} / \mathrm{ha}$. The mean yield in last three years shows that the yield of vegetables in lined pond is highest $(7.51 \mathrm{t} / \mathrm{ha})$ which is $19 \%$ higher than the unlined pond due to more number of irrigation was given to unlined pond $(6.33 \mathrm{t} / \mathrm{ha})$ and $42 \%$ higher than the no pond $(5.29 \mathrm{t} / \mathrm{ha})$ as no irrigation was given in no pond. The seepage loss in unlined pond was highest $\left(28.6 \mathrm{~m}^{3} /\right.$ day $)\left(831 \mathrm{lit} / \mathrm{day} / \mathrm{m}^{2}\right)$. The cost of lined pond was Rs 9.967/- and that of unlined pond was Rs 2,993/-. The water use efficiency was highest in lined pond (8.6 $\mathrm{kg} / \mathrm{ha} / \mathrm{mm}$ ). The cost of lining per square meter was Rs 88.5/-. Water loss in lined pond is in increasing trend where as the water loss in unlined pond is decreasing trend may be due to siltation. It is observed that tomato yield was better than the cauliflower yield. The rich farmers or farmers can dug pond can go for this technology as higher cost benefit ratio (2.25) is obtained in lined pond compared to 2.12 in unlined pond and 1.97 in no pond treatment plots. Water balance study for lined pond showed that $21.6 \%$ of the total flow into the pond is lost due to over flow, $74.5 \%$ due to seepage and evaporation. Only $3.9 \%$ of the 
Water harvesting pond and recycling for sustainable crop production in doubling income in Kandhamal district of Odisha, India.

total inflow was utilized for irrigation to crops. Biometric observation during kharif and rabi shows the lined pond got highest plant height and spread compared to others due to more number of irrigation was applied to them. It is observed that the runoff percentage is $15.4 \%$ of rainfall. Only $3.9 \%$ of is used for irrigation purpose.

\section{Techno economic analysis}

Net present worth (NPW): The net present worth of investment made on lined pond where lined pond was made is Rs 40,487/- , whereas it was Rs 15,279/- for unlined pond and Rs 8,935/- for no pond system against an investment (Total PW Cash inflow) of Rs 72,877; Rs 28,873 and Rs 18,136 respectively. Based on the NPW and BC ratio it was concluded that the lined pond is economical and there is substantial increase in income of farmer by making lined pond and using the water of lined pond for raising a second crop.

Benefit cost ratio (BCR): The benefit cost ratio for lined pond was 2.25 where as it is 2.12 in case of unlined pond. It indicates that the BCR is high in lined pond in comparison with unlined pond and no pond has lowest BCR ratio (1.97). Hence it is worth constructing the lined pond.

Internal rate of return (IRR): The interim rate of return is $66 \%$ in lined pond. Internal rate of return is more than the present interest rate i.e. $12 \%$.

Payback period: 5The table was prepared to calculate the NPP, IRR and payback period. Payback period for both lined and unlined pond were found to be two years.

Table 1: Kharif crop yield during 2007-08 to 2009-10

\begin{tabular}{|c|c|c|c|c|c|c|c|c|}
\hline \multirow[b]{2}{*}{ Treatment } & \multicolumn{4}{|c|}{ Yield of Kharif produce (t/ha) } & \multicolumn{4}{|c|}{ Yield of Rabi produce t/ha } \\
\hline & $\begin{array}{c}\text { 2007-08 } \\
\text { Cauliflower }\end{array}$ & $\begin{array}{c}\text { 2008-09 } \\
\text { Cauliflower }\end{array}$ & $\begin{array}{c}\text { 2009-10 } \\
\text { Tomato } \\
\text { (C.E.Y.) }\end{array}$ & $\begin{array}{l}\text { Mean } \\
\text { C.E.Y }\end{array}$ & $\begin{array}{l}\text { 2007-08 } \\
\text { Radish }\end{array}$ & $\begin{array}{l}\text { 2008-09 } \\
\text { Radish }\end{array}$ & $\begin{array}{c}\text { 2009-10 } \\
\text { Radish }\end{array}$ & Mean \\
\hline $\begin{array}{l}\mathrm{T}_{1} \text {-Lined } \\
\text { pond with } \\
\text { soil cement } \\
(6: 1) \text { plaster } \\
8 \mathrm{~cm} \\
\text { thickness }\end{array}$ & 4.4 & 4.8 & $\begin{array}{c}13.32 \\
(5.328)\end{array}$ & 4.843 & 22.5 & 25.5 & 23.325 & 23.775 \\
\hline $\begin{array}{l}\mathrm{T}_{2} \text {-Unlined } \\
\text { pond }\end{array}$ & 3.82 & 3.82 & $\begin{array}{l}11.35 \\
(4.54)\end{array}$ & 4.06 & & & & \\
\hline $\mathrm{T}_{3}$-No pond & 3.53 & 3.02 & $\begin{array}{c}9.33 \\
(3.732) \\
\end{array}$ & 3.427 & & & & \\
\hline Mean & 3.92 & 3.88 & $\begin{array}{c}11.33 \\
(4.533)\end{array}$ & 4.111 & & & & \\
\hline
\end{tabular}

Table 2: Water loss in different treatments

\begin{tabular}{|c|c|c|c|c|c|c|c|}
\hline Treatments & $\begin{array}{l}\text { Total } \\
\text { cost of } \\
\text { the } \\
\text { pond, } \\
\text { Rs }\end{array}$ & $\begin{array}{l}\text { Cost of } \\
\text { lining, } \\
\text { Rs }\end{array}$ & $\begin{array}{l}\text { Water } \\
\text { loss from } \\
\text { the pond } \\
\text { Lit/day }\end{array}$ & $\begin{array}{l}\text { Time } \\
\text { taken to } \\
\text { dry up } \\
\text { the } \\
\text { pond, } \\
\text { Days }\end{array}$ & $\begin{array}{l}\text { Cost of } \\
\text { storage, } \\
\text { Rs/m } / \mathrm{m}^{3}\end{array}$ & $\begin{array}{l}\text { Economics } \\
\text { loss due to } \\
\text { seepage loss } \\
\text { (Rs/day) }\end{array}$ & $\begin{array}{l}\text { Water loss, } \\
\text { lit/day/m² }\end{array}$ \\
\hline 1 & 2 & 3 & 4 & 5 & $6=(7 / 4) \times 1000$ & $7=2 / 5$ & 8 \\
\hline $\begin{array}{l}\mathrm{T}_{1} \text {-Lined } \\
\text { pond with } \\
\text { soil cement } \\
(6: 1) \text { plaster } \\
8 \mathrm{~cm} \\
\text { thickness }\end{array}$ & 9,967 & 88.5 & 235.8 & 318 & 133 & 31.34 & 17.06 \\
\hline $\begin{array}{l}\mathrm{T}_{2} \text {-Unlined } \\
\text { pond }\end{array}$ & 2,993 & 0 & 28,600 & 2.62 & 40 & 1142.37 & 831 \\
\hline $\mathrm{T}_{3}$-No pond & - & - & - & - & - & - & - \\
\hline
\end{tabular}


Table 3: Biometric observations of Kharif

\begin{tabular}{|c|c|c|c|c|c|c|c|c|c|}
\hline $\begin{array}{l}\text { Treatm } \\
\text { ent No }\end{array}$ & \multicolumn{3}{|c|}{ Plant Height(cm) } & \multicolumn{3}{|c|}{ Spread(cm) } & \multicolumn{2}{|c|}{ No of leaves } & $\begin{array}{c}\text { No of } \\
\text { branches }\end{array}$ \\
\hline Year & 2007 & 2008 & 2009 & 2007 & 2008 & 2009 & 2007 & 2008 & 2009 \\
\hline Crop & $\begin{array}{c}\text { C. } \\
\text { flower }\end{array}$ & $\begin{array}{c}\text { C. } \\
\text { flower }\end{array}$ & Tomato & $\begin{array}{c}\text { C. } \\
\text { flower }\end{array}$ & $\begin{array}{c}\text { C. } \\
\text { flower }\end{array}$ & Tomato & $\begin{array}{c}\text { C. } \\
\text { flower }\end{array}$ & $\begin{array}{c}\text { C. } \\
\text { flower }\end{array}$ & Tomato \\
\hline $\mathrm{T} 1$ & 39 & 45 & 110.2 & 51.6 & 61.6 & 71.6 & 17.6 & 17.6 & 6.2 \\
\hline $\mathrm{T} 2$ & 37.5 & 38.5 & 95.6 & 43.8 & 53.8 & 68.2 & 16.4 & 16.4 & 5.8 \\
\hline T3 & 31.2 & 32.2 & 94.6 & 36.8 & 46.8 & 66.2 & 13.2 & 14.2 & 5.2 \\
\hline
\end{tabular}

Table 4: Biometric observations of Rabi (radish)

\begin{tabular}{|l|c|c|c|c|c|c|c|c|c|}
\hline $\begin{array}{l}\text { Treatment } \\
\text { No. }\end{array}$ & \multicolumn{3}{|c|}{ Plant Height(cm) } & \multicolumn{3}{c|}{ Spread(cm) } & \multicolumn{2}{c|}{ No of leaves } & $\begin{array}{c}\text { No of } \\
\text { branches }\end{array}$ \\
\hline Year & $\mathbf{2 0 0 7}$ & $\mathbf{2 0 0 8}$ & $\mathbf{2 0 0 9}$ & $\mathbf{2 0 0 7}$ & $\mathbf{2 0 0 8}$ & $\mathbf{2 0 0 9}$ & $\mathbf{2 0 0 7}$ & $\mathbf{2 0 0 8}$ & $\mathbf{2 0 0 9}$ \\
\hline T1 & 20.8 & 25.8 & 25.5 & 44.4 & 45.4 & 44.4 & 20.8 & 26.8 & 24.8 \\
\hline
\end{tabular}

Table 5: Number of irrigation applied in different years

\begin{tabular}{|c|c|c|c|c|c|c|}
\hline \multirow[t]{2}{*}{ Treatment } & \multicolumn{3}{|c|}{ Irrigation numbers } & \multicolumn{3}{|c|}{ Quantity of water applied, lit(mm) } \\
\hline & 2007-08 & 2008-09 & 2009-10 & $2007-08$ & 2008-09 & $2009-10$ \\
\hline $\begin{array}{l}\mathrm{T}_{1} \text {-Lined pond } \\
\text { with soil cement } \\
(6: 1) \text { plaster } 8 \mathrm{~cm} \\
\text { thickness }\end{array}$ & 18 & 5 & 13 & $\begin{array}{c}600 \times 18=10,800( \\
24)\end{array}$ & $\begin{array}{c}600 \times 5=3,000( \\
6.7)\end{array}$ & $\begin{array}{c}600 \times 13=7,800(1 \\
7.33)\end{array}$ \\
\hline $\mathrm{T}_{2}$-Unlined pond & 1 & 1 & 6 & $300 \times 1=300(0.7)$ & $300(0.7)$ & $300 \times 6=1,800(4)$ \\
\hline
\end{tabular}

Table 6: Water balance in the lined pond during 2009

\begin{tabular}{|l|c|c|}
\hline \multicolumn{1}{|c|}{ Item } & Quantity (lit.) & N \\
\hline Water in the tank on 1.04.2009 & Nil & \\
\hline Water from runoff and rainfall & $2,01,753$ & 100 \\
\hline Water loss during 2009-10 & $1,50,338$ & 74.5 \\
\hline Irrigation & 7,800 & 3.9 \\
\hline Over flow & 43,615 & 21.6 \\
\hline Water on 31.03.2010 & Nil & \\
\hline Rainfdall volume & $7,60,140$ & 100 \\
\hline Runoff volume & $1,17,293$ & 15.4 \\
\hline
\end{tabular}

\section{Conclusion}

Provision of dugout pond in $10 \%$ area of the plot at the downstream side with $8 \mathrm{~cm}$ thickness soil cement plaster (6:1) gave $41 \%$ higher cauliflower equivalent yield compared to no pond. The $\mathrm{B}: \mathrm{C}$ ratio was found to be 2.25 in lined pond. The payback period for lined pond (soil cement plaster $6: 1$ of $8 \mathrm{~cm}$ thickness) is 5 years and unlined pond was estimated as 2 years.

\section{References}

Panda R.K. and Bhattacharya R.K. (1983). Lining of small irrigation channels. Journal of Irrigation and Power, 83:385391.
Panigrahi B. and Panda S.N. (2003). Optimal sizing of on-farm reservoirs for supplemental irrigation. Journal of Irrigation and Drainage Engineering (ASCE), 129(2): 117-128.

Panigrahi, B, Panda, S.N. and Agrawal, A. (2005). Water balance simulation and economics analysis for optimal size of onfarm reservoir, Water Resources Management (Springer, The Netherlands). 19 (3): 233-250.

Surajbhan (2009): Rainwater harvesting. Journal of Soil and Water Conservation, 8:42-48. 